\title{
Revivalism of Bathouism Among the Bodos
}

\author{
Faguna Barmahalia \\ Senior Research Fellow,Department of Folklore Research, Gauhati University
}

\begin{abstract}
Bathou is the traditional religion of the Bodos. This paper attempts to study on the Bathou religion of the Bodos.. The main goals of this study are to explore the origin and philosophy of Bathouism, the sociocultural significance and the role of its in Bodo society.Moreover,I will try to find out the cause of revising and giving new shape to the Bathouism.
\end{abstract}

Key words:Bathouism,traditional practices, modification, revivalism

The Bodos belong to the Indo-Mongoloid family of Tibeto Burman stock of the Assam-Burmese group. They are one of the major tribes or tribals of Assam. It can be cited that their identity is not uniform as an ethnic group. Different names are used to designate them. In West Bengal and Nepal, they are known as Meches. It is believed that the Bodos first came from South-West China through Tibet and Burma. The date of migration from their original abode, namely North Western China, to this part of present India is debated and needs further research.

The generic term 'Bodo' was first applied by Hudson to all speaking group of Tibeto-Burman languages like Bodo or Boro of the Brahmaputra valley, ${ }^{1}$ Meches of Lower Assam and west Bengal, Rabhas, Garos, Dimasas, Tipras, Lalungs, Sonowals, Hajongs, Deuris, Chutias and ohter tribes. The Bodos are living in a scattered manner throughout the North-Eastern region of India including some small Bodo pocket areas outside India in Nepal.Linguistically the Bodos include a large group of people who are the speakers of the Tibeto-Burman languages of the North and East Bengal, Assam and Burma.

\section{Bathouism as the traditional religion of the Bodos :}

The traditional religion of the Bodos is called Bathou which has been practiced since time immemorial in South East Asia. This religion is invaribaly linked up with and centred round the worship of Bathoubwrai or Sibwrai. i.e the supreme god of the Bodos. Hence it is known as Bathou religion. In the Bodo language, $\mathrm{Ba}$ means five and thou means 'deep philosophical thought'. These five elemenst are- Bar (Air), San (Sun), Ha (Earth), Or (Fire) and Okhrang (Sky). Hence, Bathou means five principles, significances which are mysterious: not easy to understand and feel without meditation. Amongst the follower of Bathou religion, God is known as the Bathou Bwrai. In Bodo language, the word Bwrai signifies the oldest or most elderly man in power and knowledge or the supreme in all respects. Therefore, he exclusively represents supreme soul, poromatma, who is omnipotent, omnicient,omnipresent. Fire can't burn him, water can't moisten, air can't dry him and spear can't pierce him. He is the illuminator of all earthly objects; He is the source of all knowledge and lights. He bestows us everything we need in this world.

The creator of these five elements is called Bathou Bwrai or the God. After creating physical form of a man with the composite elements, he confers his spirit to inanimate body which displays as the totality of living beings body. So, Bathou is religion and philosophy that embodies the spirituality of the creator or the God. The followers of Bathou religion is spirituality through the prayers, offerings and sacrifices offered to the deities. Many scholars observe regarding the religion of the Bodos. According to Sindney Endle, "the religion of the Kachari race is distinctly of the type commonly known as animistic and its underlying principle is characteristically one of fear or dead. " He again says in the same monograph-"in the typical Kachari Village as a rule neither idol nor place of worship is to be found; but to the Kachari mind and imagination earth, air and sky are alike people with a vast number of invisible spiritual beings. Known usually as mwdai, all possessing powers and faculties far greater than those of man. Mwdai is a Bodo word which means deity (God or Goddess) and should be mistaken for invisible spirits." 3 . Dr P. Bhattacharjee strongly objects "the religion of the Bodos are not animistic. They are worshippers of Bathou, the supreme God. They have other Gods and Goddesses. They believe in Ghosts and Spirits also. But the concept of the Supreme God is predominantly

\footnotetext{
1 . Hudson, B.H.1846, Miscelenous Essay Relating to Indian Subject, 105,Rev.Narzinary.Hira Charan, 1855,In Search of Indentity:The Mech: Introductory:p-21
}

2 .Endle, S. The Kacharis, 2007, p-33,Bina Library, Gauhati, Assam, India

${ }^{3}$ Ibid,p-33 
remarkable." ${ }^{4}$ The Bodo scholars and writers are of the opinion that their religion cannot be regarded as animistic. They worship Bathou. He is the illuminator of all earthly objects; he is the source of all knowledges and lights. He bestows us everything we need in this world. Frankly speaking the Bodo peoples are fundamentally nature worshippers. They are believers in the hidden power of the nature which can strongly dominate the social life. It is thought that the nature is the cause of peace and sorrow.

\section{Sijou plant (Euphorbia splendon)}

Sijou is a kind of plant whose scientific name is euphorbia splendens.The Sijou is planted in the Bathou alter at the centre as the symbol of Bathou religion of the Bodos. In Bathou religion, the Sijou plant (Euphorbia splendens) has an important place and this Sijou has been widely accepted as the symbol of life or soul by the Bodo people since time immemorial.

The Sijou plant is the living symbol of Bathoubrai, the supreme God. It needs to be mentioned here that there is no seed in sijou plant and it can survive in every place. Hence a branch from another plant is brought and planted at the Bathou altar.

\section{Bathou Altar (Bathousali) and Worship of Deities}

The Bathou altar is the main place of Bathou worship. Bodo families who follow the Bathou religion, must have a Bathousali in the North East corner of the courtyard. Apart from this, each village has to set up a Bathou altar in the community land. It contains a Bathou altar where sijou plant is planted and fenced with 18th pairs of small bamboos strips folded with five fastening which symbolises and signifies the religious and spiritual principles of Bathouism as well as the eighteen gurus and deities.

The pairs of part symbolically mean the married couple of gods and goddess, gurus as well as Mahagurus. These gurus who occupy the prominent place in the Bathou religion are: 1.Mwnsinsin bwrai and Mwnsinsin burwi, 2. Si Bwrai-Si Burwi, 3. Aham Bwrai-Aham Burwi, 4. Khuria Bwrai-Khuria Burwi, 5 .Eheo Bwrai-Eheo-Burwi 6 .Mainao Bwrai-Mainao-Burwi,7. Bwlli Bwrai-Bwlli Burwi, 8. Deva Bwrai-Devi Burwi, 9.Gongar Bwrai-Gongar Burwi, 10. Joumwn Bwrai-Joumwn Burwi, 11. Song Raja-Song Rani, 12. Hasung Bwrai-Hasung Burwi, 13. Rajong Bwrai-Rajong burwi, 14. Agrang Bwrai-Agrang Burwi, 15. Hazw BwraiHazw Burwi, 16. Emao-Bwrai-Emao Burwi, 17. Mohela Bwrai-mohela Burwi and 18. Hafao-Bwrai-HafaoBurwi. In the name of the above mentioned god and goddesses, an alari bathi (earthen lamp) is highlighted on all the altars. The first round of fastening from the bottom signifies the three bando (bindings) of human beings: birth, sorrows and pains or troubles and distress and death which have to be compulsorily borne by human bindings. No one can escape from these things. Another remaining two rounds of fastening signify the two other bindings are marriage and peace and pleasure from which one may escape.

It can be observed from above discussion that the Bathou is an ancient religion of the Bodos which has been praticed by the followers since time immorial. So, the colonial ethnographers and missionaeris called the indegenous tribal religion animism. It is also true that to a certain point the existence of Pluralistics God and Goddesses perhaps point to the primitive stage of folk religion. Beside these, there are lots of characteristics of folk religionsuchasacts like propitiation, purification, expiation, avoidance, taboo, asceticism, orgies, revelation, divination, ritual and magic are common to the traditional religion of the world.

\section{Bathou Religion in the Past}

Traditionally, the religion of the Bodos did not have any instituationalised shape. In this way the religion has since time immemorial been practised as a folk religion. But in course of time and due to the rapid changes in the society this Bathou religion has faced some new challenges. The process of worship such as sacrificing animals and fowls, offering and drinking rice beer in the name of deities appears to be crude and unfit in the eyes of the educated and civilized people. Gradually people started to dislike these processes or way of worshipping. Moreover, there was lack of uniformity in the rituals and other related matters in the same religions.

\section{Role of Organisation}

For a long time there were no preachers, no organization, no institution and no written documents to give a cohesive institutionalised shape to the Bathou religion. The modernization that comes to contact in the form of development in education, communication and exchange of ideas along with socio-economic and political implications among the tribes previously untouched by modern civilizations have huge impact in the thinking and perception of the people. Therefore, a section of the educated and consciuos Bodos have taken initiative to modify and innovate their religious pratices. As a result an organization named All Bathou Religious Union was formed in 1992. Now this organization has introduced and initiated new practices of

\footnotetext{
${ }^{4}$ Bhattacharja, P. A Descriptive Analysis of the Bodo Langauge, p-17,1997 published by Registrar,,Gauhati Univeristy Publication Department
} 
worship in the name of several deities. Since last 18 years All Bathou religious Union has been making efforts to give an organized and institutionalized shape to the Bathou religion. The main aims and objetives of the organization are to revitalise Bathouism and propagate its religious preachings all over the world, to enshrine ideas of the Bathousim along with its related traditional rites and social customs, to publish and highlight the theosophical matters, religious philosophy, thought and beliefs, moral teachings, hymns and to organize discussion, seminars, study circles and researchers as required on the Bathou religion and its philosophy from time to time. The branch organization of All Bathou Religious Union like laimwn afad (Youth wings), Mainao Afad (youth wings), preachers, prayer groups have been taking initiative regarding the changes and modification of social customs, tradition and belief. These changes of the Bodos have come under the impact of the changes in neighbouring developed other societies and religions. Workshops, seminars, discussions and conferences are frequently organised by the instititution or respective branches of ABRU. The recent moves to introduce modifiction and innovation in the religious practices are necessary to give the traditional religion a cohesive and institutionalised shape and to vitalise the religion in the days of ethnic assertion.

\section{Publication of Religious Books}

There was no written scriptures and verses in traditional Bathousim but now the ABRU is bringing out so many written holy verses, books, journals as its media of publicity, Gwthar Mwikhun (1990) is a mentionable religious concerned book which was published by Bathou publication Board, Harisinga, Assam. The central body of ABRU has also published some input publications of religions books related to Bathou religion.

\section{Establishment of Temples}

Earlier the followers of Bathousim did not have temples. Though the Bathou religion had no temples there was a worship place. Nowadays the modified Bathouism has temples known as Thansali. This is like a church of Christianity and mosque of the Islam.

Now the organisations of Bathouism are establishing their Bathousali or Bathou Thansali at their homes, head offices or regional offices. This organisation of ABRU has been playing an active role to build up its common plateform.

\section{Food offerings}

In the age old Bathou religion,there is a tradition of animal sacrifices during the observance of some worships such as Kherai, Garja and others . This process is now being revised and modified under the aiegis of Union. The followers of modified Bathousim offer flowers, fruits and prasads in the name of respective deities in place of the early and primitive pratices. They have shifted the place of worship from the temporary place of worship located outside the village, to the Bathou altar in the court-yard. In can be observed that Hindu religion has influenced the modified Bathou religion, for example the use of prasads, flower, Dhup dhuna are the clear evidence.

\section{Invention of prayer songs}

On every Tuesday, a band of singers sing prayer songs known as Bathou aroj in the Bathou altar for the well beng of the people. At the sametime, to get rid of the curses and abuses (groho nangnay) suffered by any family member, the band of singers sings prayer songs on behalf of that member in the name of the Bwrai Bathou.

\section{Role of religious specialists}

The Douri (male preist) and the Doudini (female priest) who used to play pivotal role in traditional Bathou religion are being shifted to the background. They are replaced by Gwthari Asari priest appointed by the village and a band of singers who sing i.e Bathou Aroj at the time of worship. The Douri explains the reason Raisongnay in Bodo why and to whom this worship is performed or offerred in the beginning and again the worship comes to an end with his raisongnay (concluding mantra)

The preachers and the followers of modified Bathousim have given importance on Douri instead of Douri (male priest) and Doudini (female priest). Earlier, during the Kherai worship, Doudini had to play great role in the worship. The Kherai is religious festival, and in Kherai the deities are propitiated with the ritual dance and drama. The doudini is the key dancer. As soon as the priest or oja chants the mantra, she starts dancing rhythmic dances. The doudindi moves in a circular way round the Bathou altar where deities are positioned. The oja and the deouri and the elderly members of the village follow her dancing and making hand gestures. There are eighteen varieties of dances performed by the doudini: Dahal sibnay, bathou gidingnay, Cha gwlao bwnay, khwijema fonai, dahal thungri sibnay, thungri sayao ganay, mwisw gelenai, gorai dabrainay, etc. These dances are performed with the traditional musical instruments like Kham (big drum), sifung (long flute), serza (violin) and zotha (cymbal). 


\section{Conclusion}

Bathouism is the aboriginal religion of the Bodos which provides a wide scope to wide and all embracing discipline which covers everything concerning the life, thoughts and activities of the folk. Followers of Bathouism can never run their life and society beyond their social customs and traditions as well as principles which is part and parcel of Bathouism. Bathouism have their own customs, costumes and principles relating to birth, marriage, beliefs and practices and death rites. So, Bathouism embraches all the matters. The Bathou religion plays a pivotal place in Bodo society and culture. It governs the lives of the people in their day life and in their rituals, seasonal and religious festivals. Both the life cycle ceremonies are observed according to the tenets of Bathou religion. The deep philosophical principles of Bathou exert influence on the moral character and thought of the Bodos.

\section{References:}

[1] Hudson, B.H.1846, Miscelenous Essay Relating to Indian Subject, 105,Rev.Narzinary.Hira Charan,1855,In Search of Indentity:The Mech: Introductory:p-21

[2] Endle, S. The Kacharis, 2007, p-33,Bina Library, Gauhati, Assam, India

[3] Ibid,p-33

[4] Bhattacharja, P. A Descriptive Analysis of the Bodo Langauge, p-17,1997 published by Registrar,,Gauhati Univeristy Publication Department 